\title{
A STUDY OF ACCOUNTANT REQUIRED SKILLS TO HAVE EFFICIENT PARTICIPATION IN THE IMPLEMENTATION OF XBRL
}

\author{
Heshmatolah Asadizeidabadi \\ Department of Accounting, Islamic Azad University \\ 159, 7th Boostan St., Pasdaran Ave., Sirjan, Iran \\ heshmat_alah@yahoo.com
}

\begin{abstract}
The role of the accountants in a business environment has been evolving over the years. Accountants need to have the implementation and maintenance skills of XBRL (extensible business reporting language) which is revolutionizing business reporting around the world, in the organization. The present study encompasses two aspects. First, it addresses the role of the accountant during the implementation and maintenance phase. Second, it finds the characteristics and skills of accountants that can help them in a successful implementation and maintenance of XBRL. In order to collect the data a questionnaire has been used. To analyze data two statistical methods, Regression and Pearson correlation have been used. The results of the study confirm that there is a significant relationship between the participation of accountants and successful implementation of XBRL.
\end{abstract}

Keywords: XBRL, accountant, participation and implementation

\begin{abstract}
ABSTRAK
Peran akuntan dalam lingkungan bisnis telah berkembang selama bertahun-tahun. Akuntan harus memiliki implementasi dan keterampilan pemeliharaan XBRL (bahasa bisnis pelaporan yang diperluas) yang merevolusi pelaporan bisnis di seluruh dunia, dalam organisasi. Penelitian ini meliputi dua aspek. Pertama, membahas peran akuntan selama tahap implementasi dan pemeliharaan. Kedua, menemukan karakteristik dan keterampilan akuntan yang dapat membantu mereka dalam keberhasilan pelaksanaan dan pemeliharaan XBRL. Untuk mengumpulkan data digunakan sebuah kuesioner. Untuk menganalisis data digunakan dua metode statistik, regresi dan korelasi Pearson. Hasil penelitian mengkonfirmasikan bahwa ada hubungan yang signifikan antara partisipasi akuntan dan keberhasilan pelaksanaan XBRL.
\end{abstract}

Kata kunci: XBRL, akuntan, partisipasi dan implementasi 


\section{INTRODUCTION}

The role of accountants in workplaces has gradually developed and in addition to traditional knowledge of accounting, it is necessary to have special skills. For instance, knowledge skills of drawing information systems, developing and implying of systems. Accountants who have these skills have better situations to help managers in competing, problems and new technology.

New developments in workplace environments, such as eliminating roles and laws, specialization and globalization have led to a rise of competition and a conversion of large companies to multinational ones. These changes of workplaces show that the companies should find new strategies to success and remain stable. Logically, information technology has introduced to the companies necessary instruments in order to find efficient and practical solutions to those changes. Besides, they are forces to use those technologies in competition. The prime example is XBRL (Mohammad, 2008).

XBRL is a language for the electronic communication of business and financial data which is revolutionizing business reporting around the world. It provides major benefits in the preparation, analysis and communication of business information. It offers cost savings, greater efficiency and improved accuracy and reliability to all those involved in supplying or using financial data (XBRL International, 2007) it has suggested that XBRL is very likely to have an impact on corporations, financial reporting, users of financial reports and auditing (Baldwin \& Trinkle, 2011).

XBRL will provide the ability to access data electronically and continuously will improve the timeliness of the financial information (Bovee et al. 2002; Bonson, 2009). As the timeliness improves, the efficiency of the decision making process is improved (Dipiazza and Eccles, 2002). And XBRL has been used to automate and integrate changing financial information from multiple sources as it has said about XBRL applications (Marshall et al, 2010; Burnett et al, 2006; Bovee et al, 2005).

According to The Futurist, XBRL is one of seven cutting-edge technologies that will have a big impact on business and revolutionize corporate performance (The Futurist, 2003). Research has been done about the importance of XBRL for business for example by (Pinsker, 2003; Rezaee et al, 2002; DiPiazza and Eccles 2002; Bovee et al, 2002 and Bonson, 2009) its usefulness confirmed but it has not been used very much (Zhu Wenming, 2007) so that this study is going to examine the accountants required skills to have efficient participation in the implementation of XBRL.

Extensible Business Reporting Language (XBRL) is an XML based specification that uses accepted financial reporting standards and practices to export financial reports across all software and technologies, including the internet (Junsi, 2007). XBRL allows your company to make betterinformed decisions and to leverage the capabilities of the internet to facilitate the exchange of financial information (Microsoft, 2002).

First introduced in the late 1990s, XBRL has loomed on the horizon for nearly a decade. But it's finally becoming evident that the technology is about to take center stage, and the long-anticipated XBRL revolution will soon be upon us. Many regulators and standards organizations, including the Securities and Exchange Commission are now adopting XBRL (Montgomery Research, 2002).

Keys of its Benefits are: Technical independence -XBRL makes the distribution of financial information simpler and more dependable; Single source- XBRL optimizes the preparation of financial information in various formats; Leverages the power of the Internet (Microsoft, 2002). 
As the founding chairman of XBRL International describes it, "The effect that XBRL will have on the business community will be more significant than the transition from paper and pencil analysis of financial information to the use of electronic spreadsheets (Montgomery Research, 2002). Because of XBRL importance, it is important to know what factors impact on its usage among accountants, so this has been conducted by current article.

\section{METHOD}

This research has been examined required skills of accountants to implementing XBRL. Sample of this research will be 155 of accountants in Iran. They have been contacted electronically and aids and importance of research has been explained. A questionnaire has been developed and distributed to a sample of the research, accountants in Iran. The questionnaire has been distributed electronically.

SPSS 18 has been used to analyze data, and the answers to the questionnaire have been analyzed with the statistical methods: Pearson Correlation and Regression. In order to determine the number of relationship between success of implementing XBRL systems and accountants' participation, two methods of Pearson Correlation and Regression has been used.

\section{RESULTS AND DISCUSSION}

Results of Table 1 show Pearson correlation data in which the relation between those variables is direct and significant $(\mathrm{P}<0.01)$. In the other words, a rise of accountants' participation, similarly implementing XBRL systems would increase and diverse.

Table 1 The Relationship Between Success of XBRL Implementation and Accountants' Participation in Implementation

\begin{tabular}{lccc}
\hline Variable & $\begin{array}{l}\text { Accountants’ participation } \\
\text { in implementing XBRL }\end{array}$ & Significance level & Number \\
\hline $\begin{array}{l}\text { Success of XBRL } \\
\text { implementation }\end{array}$ & $0.624^{* *}$ & 0.000 & 155 \\
\hline & $\mathrm{P}<0.05^{*}$ & $\mathrm{p}<0.01^{* *}$ &
\end{tabular}

Table 2 illustrates that slope of a regression line is significant $(\mathrm{P}<0.05)$.

Table 2 Accountants' Participation in Implementing XBRL

\begin{tabular}{lccccc}
\hline \multicolumn{1}{c}{ Model } & \multicolumn{2}{c}{ Non standardized coefficients } & $\begin{array}{c}\text { Standardized } \\
\text { coefficients }\end{array}$ & T & Significance \\
\cline { 2 - 5 } & Sample slope B & $\begin{array}{c}\text { Standard error } \\
\text { slope line }\end{array}$ & Population slope & 6.24 & 0.000 \\
\hline Intercept & 1.72 & 0.34 & - & 9.03 & 0.000 \\
$\begin{array}{l}\text { Slope of } \\
\text { a regression line }\end{array}$ & 0.61 & 0.7 & 0.624 & \\
\hline
\end{tabular}

As it shows in Table 3, there is not a significant relation between skills of knowledge sharing and accountants' acceptance in implementing XBRL. It means that increase or decrease of skills of knowledge sharing does not relate to accountants' acceptance in implementing XBRL. 
Table 3 Relationship Between Skills of Knowledge Sharing and Accountants' Acceptance in Implementing XBRL

\begin{tabular}{|c|c|c|c|c|c|}
\hline \multirow[t]{2}{*}{ Model } & \multicolumn{2}{|c|}{ Non standardized coefficients } & \multirow{2}{*}{$\begin{array}{c}\begin{array}{c}\text { Standardized } \\
\text { coefficients }\end{array} \\
\text { Population slope }\end{array}$} & \multirow[t]{2}{*}{$\mathrm{T}$} & \multirow[t]{2}{*}{ Significance } \\
\hline & Sample slope b & $\begin{array}{c}\text { Standard error } \\
\text { slope line }\end{array}$ & & & \\
\hline Intercept & 5.23 & 0.121 & - & 51.32 & 0.000 \\
\hline $\begin{array}{l}\text { Slope of } \\
\text { a regression line }\end{array}$ & 0.071 & 0.068 & 0.099 & 1.13 & 0.38 \\
\hline
\end{tabular}

To determine the number of relationship between skills of knowledge sharing and accountants' acceptance Regression has been used, which in Table 4, shows the relation between them is direct and significant. In other words, a rise of accountants' participation, similarly implementing XBRL systems would increase and diversely.

Table 4 Relationship Between Skills of Knowledge Sharing and Accountants' Acceptance in Storage of XBRL

\begin{tabular}{llclll}
\hline \multicolumn{1}{c}{ Model } & \multicolumn{2}{c}{ Non standardized coefficients } & $\begin{array}{c}\text { Standardized } \\
\text { coefficients }\end{array}$ & T & Significance \\
\cline { 2 - 5 } & Sample slope b & $\begin{array}{c}\text { Standard error slope } \\
\text { line }\end{array}$ & $\begin{array}{c}\text { Population } \\
\text { slope }\end{array}$ & & \\
\hline $\begin{array}{l}\text { Intercept } \\
\begin{array}{l}\text { Slope of } \\
\text { a regression line }\end{array}\end{array}$ & 5.70 & 0.113 & - & 54.57 & 0.000 \\
\hline
\end{tabular}

The relation between technical skills and accountants' acceptance in implementing XBRL has been assessed by Regression, which in Table 5, shows the relation between them is direct and significant $(\mathrm{P}<0.05)$. In the other word, a rise of accountants' participation, similarly implementing XBRL systems would increase and diversely.

Table 5 Relationship Between Technical Skills and Accountants' Acceptance in Implementing XBRL

\begin{tabular}{|c|c|c|c|c|c|}
\hline \multirow[t]{2}{*}{ Model } & \multicolumn{2}{|c|}{ Non standardized coefficients } & \multirow{2}{*}{\begin{tabular}{|c|}
$\begin{array}{c}\text { Standardized } \\
\text { coefficients }\end{array}$ \\
$\begin{array}{c}\text { Population } \\
\text { slope }\end{array}$
\end{tabular}} & \multirow[t]{2}{*}{$\mathrm{T}$} & \multirow[t]{2}{*}{ Significance } \\
\hline & Sample slope B & $\begin{array}{c}\text { Standard error } \\
\text { slope line }\end{array}$ & & & \\
\hline Intercept & 5.70 & 0.113 & - & 54.57 & 0.000 \\
\hline $\begin{array}{l}\text { Slope of } \\
\text { a regression line }\end{array}$ & 0.663 & 0.102 & 0.546 & 7.05 & 0.000 \\
\hline
\end{tabular}

To assess the relation between technical skills and accountants' acceptance in storage of XBRL has been used Regression, which in Table 6, shows the relation between them is direct and significant $(\mathrm{P}<0.05)$. In the other word, a rise of technical skills, similarly accountants' acceptance in storage of XBRL would increase and diversely. 
Table 6 Relationship Between Technical Skills and Accountants' Acceptance in Storage of XBRL

\begin{tabular}{|c|c|c|c|c|c|}
\hline \multirow[t]{2}{*}{ Model } & \multicolumn{2}{|c|}{ Non standardized coefficients } & \multirow{2}{*}{$\begin{array}{c}\text { Standardized } \\
\text { coefficients } \\
\text { Population } \\
\text { slope } \\
\end{array}$} & \multirow[t]{2}{*}{$\mathrm{T}$} & \multirow[t]{2}{*}{ Significance } \\
\hline & Sample slope B & $\begin{array}{l}\text { Standard error } \\
\text { slope line }\end{array}$ & & & \\
\hline Intercept & 6.99 & 0.178 & - & 42.01 & 0.000 \\
\hline $\begin{array}{l}\text { Slope of } \\
\text { a regression line }\end{array}$ & 0.96 & 0.97 & 0.660 & 10.11 & 0.000 \\
\hline
\end{tabular}

Regarding to Table 7, there is no relation between trade skills and accountants' acceptance in implementing XBRL base on result of regression analysis.

Table 7 Relationship Between Trade Skills and Accountants' Acceptance in Implementing XBRL

\begin{tabular}{|c|c|c|c|c|c|}
\hline \multirow[t]{2}{*}{ Model } & \multicolumn{2}{|c|}{ Non standardized coefficients } & Standardized & $\mathrm{T}$ & Significance \\
\hline & Sample slope B & $\begin{array}{c}\text { Standard error } \\
\text { slope line }\end{array}$ & $\begin{array}{l}\text { Population } \\
\text { slope }\end{array}$ & & \\
\hline Intercept & 5.412 & 0.174 & - & 32.3 & 0.000 \\
\hline $\begin{array}{l}\text { Slope of } \\
\text { a regression line }\end{array}$ & 0.008 & 0.17 & 0.005 & 0.011 & 0.998 \\
\hline
\end{tabular}

According to Table 8, there is no relation between trade skills and accountants' acceptance in storage of XBRL base on result of regression analysis.

Table 8 Relationship Between Trade Skills and Accountants’ Acceptance in Storage of XBRL

\begin{tabular}{|c|c|c|c|c|c|}
\hline \multirow[t]{2}{*}{ Model } & \multicolumn{2}{|c|}{ Non standardized coefficients } & \multirow{2}{*}{$\begin{array}{c}\text { Standardized } \\
\text { coefficients } \\
\text { Population } \\
\text { slope } \\
\end{array}$} & \multirow[t]{2}{*}{$\mathrm{T}$} & \multirow[t]{2}{*}{ Significance } \\
\hline & Sample slope B & $\begin{array}{c}\text { Standard error slope } \\
\text { line }\end{array}$ & & & \\
\hline Intercept & 5.297 & 0.123 & - & 44.892 & 0.000 \\
\hline $\begin{array}{l}\text { Slope of } \\
\text { a regression line }\end{array}$ & 0.136 & 0.091 & 0.16 & 1.634 & 0.141 \\
\hline
\end{tabular}

\section{CONCLUSION}

In the future, it is expected many companies to integrate XBRL and their automated accounting information systems. to provide this situation, accountants should have an important and practical role, due to this issue. This article has investigated required skills and role of accountants to practically implement XBRL, in which the results clearly show that the accountants have key roles in implementing and storage of XBRL systems. Previous research has justified that role of accountants have changed with developing information technology (Jean-Baptiste, 2006), and also some studies state significant role of XBRL in business (Pinsker, 2003; Rezaee et al., 2002; DiPiazza and Eccles, 2002; Bovee et al., 2002; Bonson, 2009). 


\section{REFERENCES}

Baldwin, Amelia A. \& Trinkle, Brad S. (2011). The impact of XBRL: A Delphi investigation. The International Journal of Digital Accounting Research, 11, 1 - 24.

Bonson, E., Cortijo, V., \& Escobar, T. (2009). A Delphi investigation to explain the voluntary adoption of XBRL. The International Journal of Digital Accounting Research, 193 - 205.

Bovee, M., Ettredge, M. L., Srivastava, R. P., \& Vasarhelyi, M. A. (2002). Does the year 2000 XBRL taxonomy accommodate current business financial-reporting practice? Journal of Information Systems, 16, $165-182$.

Bovee, M., Kogan, A., Nelson, K., Srivastava, R., \& Vasarhelyi, M. A. (2005). Financial Reporting and Auditing Agent with Net Knowledge (FRAANK) and eXtensible Business Reporting Language (XBRL). Journal of Information Systems, 19, 19 - 41.

Burnett, R. D., Friedman, M., \& Murthy, U,. (2006). Financial reports: Why you need XBRL. Journal of Corporate Accounting and Finance, 5, 33 - 40.

Dipiazza, S. A. Jr., Eccles, R. G. (2002). Building public trust. The Internet. New Jersey: John Wiley \& Sons.

Jean-Baptiste, Rodney (2006), The Role of Accountants in the Implementation and Maintenance of Enterprise Resource Planning Systems. Capella University, Minneapolis.

Junsi, Li. (2007). XBRL taxonomy review and comparison between IFRS-GP taxonomy and CN listed company taxonomy (Master of Science thesis in accounting, Swedish school of economics and business administration).

Marshall, B., Mortenson, K., Bourne, A., \& Price, K. (2010). Visualizing basic accounting flows: Does XBRL + model + animation = understanding? The International Journal of Digital Accounting Research, 10, 27 - 54.

Microsoft. (2002). Navision became part of Microsoft business solutions. Retrived from http://www.microsoft.com/.

Mohammad, Arab Mazar Yazdi. (2008). A study of impact of ERP on accounting process. Accountand journal, 180, 72-79.

Montgomery Research. (2002). Shared Services, Outsourcing and Enterprise Solutions. Competitive Financial Operations The CFO Project, 1.

Pinsker, R. (2003). XBRL awareness in auditing: A sleeping giant? Managerial Auditing Journal, 18, $732-736$.

Rezaee, Z., Sharbatoghlie, A., Elam, R., \& Mcmickle, P. L. (2002). Continuous auditing: Building automated auditing capability. Auditing: A Journal of Practice \& Theory, 21, $147-163$.

The Futurist. (2003). Technologies benefiting business. The Futurist, 37, 2 - 7. 
XBRL International. (2007). XBRL International Progress Report. Retrived from http://www.xbrl.org/progressreports/2007_11_xbrl_progress_report.pdf.

Zhu Wenming. (2007). Continuous online auditing in the government sector. International Auditor. Retrieved from http://www.theiia.org/intAuditor/itaudit/archives/2007/june/continuous-onlineauditing-in-the-government-sector/. 